\title{
Preservation and value addition of fish salaya (Sardinella gibbosa)
}

\author{
By
}

HAEMAH VAIKUNTHARAJA 


\section{Declaration of Candidate}

The work described in this thesis was carried out by me under the supervision of Prof. Arthur Bamunuarachchi and a report on this has not been submitted in whole or in part to any university or any other institution for another degree / diploma.

Date: $24 \cdot 11.2006$

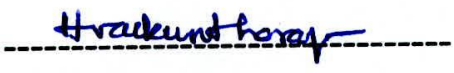

Haemah. Vaikuntharaja 


\section{Declaration of Supervisor}

I, Prof. Arthur Bamunuarachchi certify that the above statement made by the candidate is true and that this thesis is suitable for submission to the University for the purpose of evaluation.

Date: $27 /$ ter

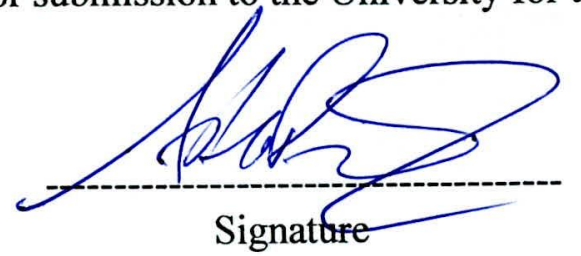

Prof. Arthur Bamunuarachchi,

Coordinator Food Science and Technology Programs,

Department Of Food Science and Technology,

University of Sri Jayewardenepura,

Sri Lanka. 
TABLE OF CONTENTS

Contents

Page No

Lists of Tables

vi

Lists of figures

vii

Acknowledgements

viii

Abbreviations

ix

Abstract

$\mathrm{x}$

CHAPTER 1

1 Introduction

\section{CHAPTER 2}

$2 \quad$ Literature review

2.1 About the fish Sardinella gibbosa (Goldstripe Sardinella)

2.1.1 Distribution

2.12 Interest to fisheries of fish salaya

2.2 Nutritive value of fish

2.2.1 Protein

2.2.2 Polyunsaturated Fatty acids

2.2.3 Vitamins and minerals 
2.2.4 Average composition of fish

$\begin{array}{lll}2.3 & \text { Principle of Drying and steaming } & 14\end{array}$

$\begin{array}{lll}2.3 .1 & \text { Drying } & 15\end{array}$

2.3.2 Dryers 16-18

$2.4 \quad$ Value addition of fish $19-20$

$\begin{array}{lll}2.4 .1 & \text { Quality assurance } & 21\end{array}$

$\begin{array}{ll}\text { 2.4.2 Marketing and distribution } & 21\end{array}$

$\begin{array}{lll}2.4 .3 & \text { Trade barriers } & 22\end{array}$

2.4.4 Packaging of dried fish products 23

2.5 Potential Food Safety Hazard 23

$\begin{array}{lll}2.5 .1 & \text { Control Measures } & 23\end{array}$

$\begin{array}{ll}\text { 2.5.2 Process Establishment } 25 & 25\end{array}$

2.5.3 Critical Aspects of Processes 26

2.5.4 Quality control system in the industry 26

2.5.6 Modern concept of preventive quality control 27

2.5.6.1 The HACCP concept 27-28

$\begin{array}{ll}2.6 & \text { Chemical Analysis }\end{array}$

$\begin{array}{llr}2.7 & \text { Microbiological measurement } & \text { 31-32 }\end{array}$

2.8 Sensory evaluations 33

2.8.1 Location and Layout $\quad 34$

$\begin{array}{lll}\text { 2.8.2 Preparation area } & 34\end{array}$

2.8.3 Evaluation Area 35 


\section{CHAPTER 3}

3 Experimental

3.1 Preservation of fish Salaya by steaming and drying process 37

$\begin{array}{lll}3.1 .1 & \text { Materials } & 37\end{array}$

$\begin{array}{lll}\text { 3.1.2 Method } & 37\end{array}$

3.2 Value addition of fish Salaya 38

$\begin{array}{lll}3.2 .1 & \text { Materials } & 38\end{array}$

3.2.2 Method 39

3.3 Determination of Chemical Physical and Microbial Parameters40

3.3.1 Studies on Chemical parameters $\quad 40$

3.3.1.1Determination of Moisture content of fish samples 40

3.3.1.1.1 Materials $\quad 40$

3.3.1.1.2 Method 40

3.3.1.2 Determination of Trimethylamine content of fish samples.

3.3.1.2.1Materials 41

3.3.1.2.2 Method 42

3.3.2. Studies on Physical Parameters 43

3.3.2.1Determination of the $\mathrm{pH}$ value of the samples $\quad 43$

$\begin{array}{ll}\text { 3.3.2.1.1Materials } & 43\end{array}$

3.3.2.1.2Method 43

3.3.3 Studies on microbial parameters. 44 
3.3.3.1Estimation of Total microbial count

(Aerobic plate count) of Fish samples $\quad 44$

3.3.3.1.1Material $\quad 44$

3.3.3.1.2 Method 45

$\begin{array}{lll}3.4 & \text { Sensory evaluation } & 46\end{array}$

$\begin{array}{lll}3.4 .1 & \text { Material } & 46\end{array}$

$\begin{array}{lll}\text { 3.4.2 Method 46-47 } & \text { 46 }\end{array}$

\section{CHAPTER 04}

Results and discussion $\quad$ - $\quad 48$

4.1 Moisture Content : $\cdots \quad 49-51$

4.2 Trimethyl amine contenit $\bullet \quad \therefore \quad 52-54$

$\begin{array}{lll}4.3 & \text { pH measurements } & 54\end{array}$

4.4 Microbial counts $\quad 55$

4.5 Sensory evaluation of the three fish Samples 56

4.5.1 ANOVA scores for appearance 59

4.5. 2 The ANOVA scores for Texture test 60

4.5.3 ANOVA scores for Odour 60 
CHAPTER 05

$\begin{array}{ll}\text { DISCUSSION } & 61\end{array}$

$\begin{array}{lll}\text { 5.1 Moisture Content } & 61\end{array}$

$\begin{array}{lll}5.2 & \text { Trimethyl amine content } & 61\end{array}$

$\begin{array}{lll}5.3 & \text { pH measurements } & 63\end{array}$

$\begin{array}{llr}5.4 & \text { Microbial counts } & 63-64\end{array}$

5.5 Sensory evaluation of the three fish Samples 65

$\begin{array}{lrl}\text { CONCLUSIONS } & 66-67\end{array}$

$\begin{array}{lr}\text { REFERENCES } & 68-69\end{array}$

$\begin{array}{ll}\text { APPENDIX } 1 & 70\end{array}$

$\begin{array}{ll}\text { APPENDIX } 11 & 71\end{array}$

$\begin{array}{ll}\text { APPENDIX } 111 & 73\end{array}$

$\begin{array}{ll}\text { APPENDIX 1V } & 76\end{array}$ 


\section{Lists of Tables}

Table 1 Weight of the fish sample for the first 6 hours of drying 48

Table 2 Moisture contents of dried fish samples during storage

of 3 months

Table3 Moisture contents of value added fish sample during storage of three months

Table 4 Trimethylamine contents of dried fish during storage of 3 months

Table 5 Trimethylamine contents of value added fish during storage of three months

Table8 $\quad \mathrm{pH}$ values of fresh and dried fish samples 54

Table 9 Total microbial counts in fish samples 55

Table10 Category scores of hedonic test for appearance 56

Table $11 \quad$ Category scores of hedonic test for Texture 57

Table12 Category scores of hedonic test for Odour 58

Table12 Grand totals of the three hedonic tests of fish samples 59

Table 13 The ANOVA scores for appearance test 59

Table14 The ANOVA scores for Texture test 60

$\begin{array}{lll}\text { Table } 15 & \text { ANOVA scores for odour test }\end{array}$ 


\section{Lists of figures}

\section{Page no}

$\begin{array}{lll}\text { Figure } 1 & \text { Photo of Sardinella gibbosa }\end{array}$

Figure 2 Geographical Distribution of Sardinella gibbosa $\quad 8$

Figure 3 Capture Production for Sardinella gibbosa (Indonesia) 9

Figure 4 Landings in Sri Lanka-E Indian Ocean (Sardinella gibbosa) 10

$\begin{array}{llr}\text { Figure } 5 & \text { Dryers } & 17-18\end{array}$

Figure $6 \quad$ Plan of a laboratory for sensory evaluation 35

Figure7 Drying curve of the fish sample for the first 6 hours of drying.

Weight of the fishes in the oven Vs time

Figure 8 Moisture contents of the dried fish during the storage of

3 months (Moisture content Vs weeks)

Figure 9 Moisture contents of the value added fish sample

during the storage period(Moisture content Vs weeks)

Figure $10 \quad$ Trimethylamine contents of dried fish Vs storage period

Storage of three months. (Moisture content Vs weeks)

Figure 11 Trimethylamine content of value added fish samples Vs

Storage period 


\section{Abbreviations}

$\begin{array}{ll}\text { APC } & \text {-Aerobic plate counts } \\ \text { cfu } & \text {-Colony forming units } \\ \text { DMA } & \text {-Dimethylamine } \\ \text { DHA } & \text { - Docosa hexaenoic acid } \\ \text { EPA } & \text { - Eicosa pentaenoic acid } \\ \text { PUFA } & \text { - Polyunsaturated Fatty acids } \\ \text { TBC } & \text {-Total bacterial count } \\ \text { TMA } & \text {-Trimethylamine } \\ \text { TMAO } & \text {-Trimethylamine oxide } \\ \text { TVB-N } & \text {-Total volatile basic nitrogen } \\ \text { TVC } & \text {-Total Viable count }\end{array}$




\section{ACKNOWLEDGEMENTS}

I would like to express my sincere thanks to my supervisor, Professor. Arthur Bamunuarachchi, Coordinator Food Science and Technology Programs, Department of Food science and Technology, Faculty of Applied sciences, University Of Sri Jayawardanapura for his guidance, advice and encouragement throughout the period of study to complete it successfully.

Also my thanks goes to Dr.K.K.D.S Ranaweera, the research Coordinator Food Science and Technology Programs, and Head of Department of Food science and Technology, Faculty of Applied sciences, University Of Sri Jayawardanapura for helping me throughout this research work and for the advice given to me regarding my research.

My special thanks are due to the staff of the Department of Food science and Technology, Specially to Mrs.Rupika.Perera, Mr SisiraWeerasinge and Mr.D.P Rubasinge. Also, I would like to take this opportunity to thank all the members of the laboratory staff in the Department of Food science and Technology for the help given.

I am also indebted to my colleagues of the M.Sc course in Food Science and Technology who encouraged and helped me in many ways. I also thank my Husband, father mother and all others too, who helped me in my research in various ways. 


\begin{abstract}
This report deals with some of quality parameters and sensory evaluation of steamed dried fish and value added fish.

Preservation and value addition of fish salaya is becoming one of the important things nowadays. Because, Salaya fish is a world species of interest to fisheries. Since 1972, the catches of this species have been steadily increasing almost every year and also Salaya provides a good source of protein and contains many vitamins and minerals and essential fatty acids, all of which are vital for the healthy functioning of the body.
\end{abstract}

The goal of this project was to preserve fish salaya without any chemicals with a minimum cost, even salt was not used in this process of preserving salaya and develops new knowledge to increase the value of underutilized fish salaya. This was achieved by accomplishing good practices of collection and storage of the fish, to retain the chemical, biological, and physical qualities of the fish and developing new and improved value added products. In the process of value addition, spices and vinegar were used as ingredients. These ingredients not only give taste and flavours but also contain a lot of medicinal uses. They also control the microbial activity to some extent.

The process involved were steaming and drying .In this process steaming cooks the fish partially and at the same time kills micro organisms. Drying process 
reduces the moisture content, thus available water for growth of microorganisms is also reduced.

In this process artificial drier was used for drying. Artificial drier can increase drying rates and produce lower moisture content in the final products, with improvements in fish quality compared with the traditional sun-drying techniques.

The product was subjected to chemical, physical and microbial analyses during the storage period. Sensory evaluation was also done at the end of the storage period.

Moisture contents of the dried fish samples and value added fish samples were determined at every two weeks intervals. The moisture contents gradually increased during the storage period of three months.

The maximum moisture content of the dried fish during the storage period was 9.98\%. The fish products can be kept without any damage as long as the moisture content is below $11-12 \%$.

Trimethylamine contents of the dried fish samples and value added fish samples were determined at every two weeks intervals. The Trimethylamine contents gradually increased during the storage period of three months.

The maximum Trimethylamine (TMA) value of the fish product during the storage was $16.3 \mathrm{mg} / 100 \mathrm{~g}$ that also did not exceed the marketable level of TMA (26 mg/ 100g).

Microbial analysis were done on dried fish samples and value added fish samples 
The results showed that, the microbial content was in the acceptable range (total viable counts of $10^{2}-10^{6} \mathrm{cfu} / \mathrm{g}$ are common on whole fish).

Sensory evaluation is used in the testing of fishery products for conformity requirements. Three types of samples (dried fish, Value added fish, and dried fish -salaya bought from supermarket) were evaluated by 12 assessors. From the results of evaluation statistical analyses were done.

Sensory evaluation also proved that, there was no significant difference among the fishes preserved by this process and the dry fish already available in the market.

Considering the quality attributes, it could be concluded that the preserved fishes is marketable and consumable within three months of its production. 